\title{
Ten minutes with Dr Raed A Dweik, Chairman of the Respiratory Institute at the Cleveland Clinic
}

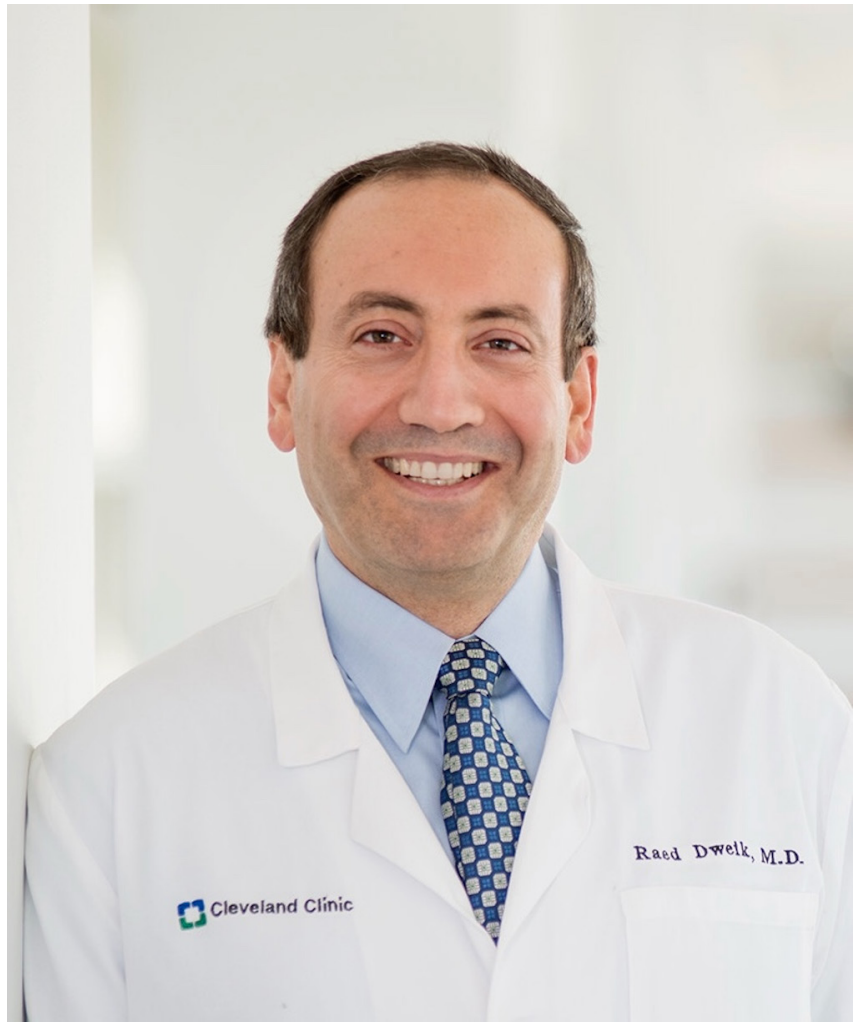

FIRST AND FOREMOST, ARE THERE ANY KEY LEADERSHIP MESSAGES YOU WANT TO GET OUT TO OUR READERSHIP?

Communication, transparency, trust, time management and planning.

Communication and transparency are key. Do it early, do it often. One important point to make is that communication is more about listening than talking! Many people think that they have communicated when they have told you something! The reality is that communication is not complete until you have listened. I have had hour-long meetings where I spoke for less than 5 minutes, and people felt I was a great communicator! And I have been at hour-long meetings where one person spoke most of the time and people felt they did not communicate much at all! Communication is even more important in times of uncertainty. As we prepared for the COVID-19 pandemic, I started with daily calls with leadership (the Respiratory Institute Incident Command) at 7:00 and 17:00, along with twice daily 9:00 and 12:30 pulse checks open to all employees in the entire institute, in addition to emails. As we got to a point where most questions and concerns are addressed, we switched to a daily pulse check calls with all at noon and a daily leadership call at $5 \mathrm{pm}$.

Trust. Having built trust with the team before allowed us to move much faster in implementing new initiatives, including some drastic changes. The key to building trust is to say what you mean and mean what you say: as evidenced by your actions.

Time is our most valuable (and arguably our only) asset. Time is money, time is family, time is work, and so on. How we

\section{Biography}

Raed A Dweik, MD, MBA, is the Chairman of the Respiratory Institute at Cleveland Clinic. He is board-certified in internal medicine, pulmonary disease and critical care medicine. Dr Dweik's clinical interests are in pulmonary disease, pulmonary hypertension, asthma, chronic beryllium disease and critical care.

$\mathrm{He}$ is Professor of Medicine in the Lerner College of Medicine and has a joint appointment in the Lerner Research Institute, with continuous funding from the National Institutes of Health (NIH) since 2002. He has published more than 250 peer-reviewed manuscripts and book chapters and serves on several journal editorial boards, NIH review panels, and American Thoracic Society, American Heart Association and Association of American Medical Colleges committees.

Dr Dweik is a Fellow of the American College of Physicians, the Royal College of Physicians of Canada, the American College of Chest Physicians, the Society of Critical Care Medicine, the American Heart Association, the Pulmonary Vascular Research Institute and the American Thoracic Society.

Dr Dweik earned his medical degree from the University of Jordan before moving to the USA for internal medicine training at Wright State University, followed by a fellowship in Pulmonary and Critical Medicine at Cleveland Clinic. He earned an MBA from Case Western Reserve University.

manage and spend our time determines how and what we do in any situation.

Planning. As it has been said 'plans are worthless but planning is everything'. This crisis has been a great example of this. When the first case was identified in the USA, my leadership team and I went on high alert. When the first case was identified in our state of Ohio, we went into all-hands-on-deck mode. We learned a lot from talking to people in places that experienced the pandemic before us, from China, to Italy, to the UK, and more recently Washington State and New York. We quickly realised the importance of focusing on three areas as we prepare: space (hospital and intensive care unit (ICU) beds, cohorting, etc), staff (physicians, advanced practice providers, trainees, respiratory therapists, nurses, etc) and stuff ((personal protective equipment (PPE), ventilators, etc).

\section{TELL US A LITTLE BIT ABOUT YOUR LEADERSHIP ROLE AND HOW IT IS CHANGING AS A RESULT OF THE PANDEMIC?}

I lead the Respiratory Institute at the Cleveland Clinic which is home to pulmonary medicine, critical care, infectious diseases and allergy/immunology. So we are at the forefront of the fight against COVID-19. Before the pandemic, we offered a wide range of medical services, but over the past few weeks we had to refocus our resources on COVID-19. We stopped non-essential procedures, shifted caregivers from outpatient to inpatient services, and established COVID-19 cohort units, etc. I have always viewed myself as a serving leader who empowers others to lead with a hands-off, eyes-on approach trying to delegate whenever possible. In return, I expect ownership from the person or team I delegate to. An important part of this approach is to know what/when not to delegate. 


\section{WHAT EVENTS IN YOUR PAST EXPERIENCE ARE MOST INFORMING YOUR LEADERSHIP IN THIS PANDEMIC?}

Believe it or not, this reminded me of being an intern and resident in training again. Maybe internship was a personal crisis and COVID-19 is a global one. I use the acronym REST: Rest when you can, Eat when you can, Sleep when you can and Train when you can. In this case training means learning what you can about COVID-19.

\section{WHAT ARE YOU FINDING THE BIGGEST CHALLENGES?}

Uncertainty. This is a previously unknown virus causing a pandemic with unknown behaviour. Many models and simulations are out there telling us completely different things. This makes the role of leadership even more critical than ever. One of the most important qualities of leaders is the ability to take and absorb people's fears and anxieties at times of uncertainty. Seeing not just what's in front of us but also what is around the corner, and being able to make decisions with limited information in the face of ambiguity. Anybody can lead in certain times. It is times of uncertainty that test leadership. Moments of absolute certainty are rare and leaders need to be able to handle ambiguity when making decisions. Rarely do we have all the facts to make a decision. The key is to focus on what we know and do our best in anticipating what's coming including best and worst case scenarios. Similar to what I tell my critically ill patients and their families: hope for the best and prepare for the worst.

\section{ANY PARTICULAR SURPRISES?}

Pandemics can bring the best and worst in people. You'd be surprised who really steps up and runs towards it, and who wants to hide. I had some people anxious and worried about themselves and their families, and others who literally cried when I sent them home because they were sick or not needed. They wanted to be there and help. I've seen both sides of the human response, and fortunately the vast majority, 99.9\%, of people are stepping up. When I have my daily meetings with our caregivers, I frequently finish by thanking them for what they do every day and for leading the way in this fight. I also remind them that as healthcare professionals, we have been preparing all our lives for this! This is our calling! And together we can do it!

\section{ARE YOU SEEING ANY BEHAVIOURS FROM COLLEAGUES THAT ENCOURAGE OR INSPIRE YOU?}

The things that stand out are teamwork and innovation. We had to build teams that did not exist before. We had to get people from different areas who either worked peripherally together before, or never worked together at all. Our teams have been

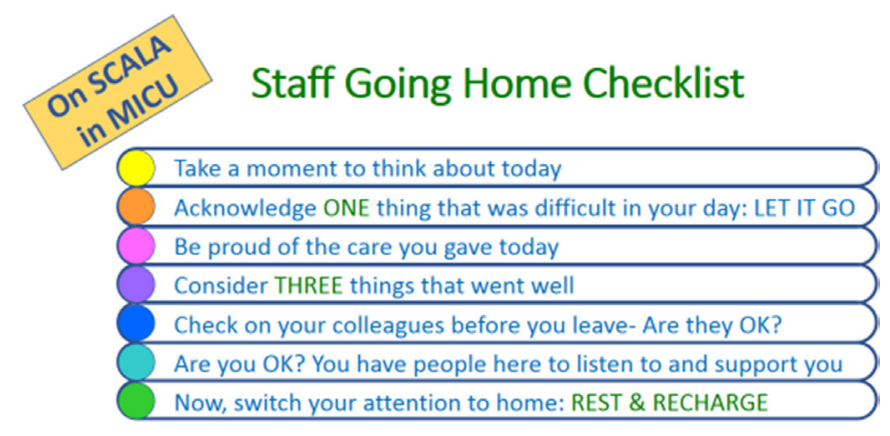

Closing rituals are designed to bring closure to the day's experiences, helping you move forward with less stress and more focus. This checklist provides guidance on developing a ritual that's all your own. highly innovative. Doing things like placing the controls of ventilators, intravenous infusion pumps (IV pumps) or dialysis machines outside the room to minimise exposure. Teams also innovated in how to communicate with families virtually at the times when they cannot visit their loved ones.

Other areas are education and research. In medicine we are continuously learning, but the COVID-19 pandemic created an urgent need for a different type of education. We had to educate our caregivers very quickly about COVID-19, but we also needed to prepare non-critical care people to help in case they were needed. Research has been a central piece especially because there are no proven or approved treatments for COVID-19. While some places started using unproven treatments empirically and without evidence, we decided to stick to evidence-based therapies. We evaluated the evidence and started or participated in several clinical trials. Due to the large number of proposed trials, we established a team to vet these trials regarding scientific merit and potential benefit to our patients.

\section{HOW ARE YOU MAINTAINING KINDNESS AND COMPASSION?}

It's almost serendipity I have to say that a few months before all this happened and because of the general trends of burn-out in medicine, we created a new position for an Institute Wellness Officer. This could not have come at a more appropriate time because now our caregivers are under a lot of stress. Our Wellness Officer has done a wonderful job keeping us all taken care of and connected. She created neighbourhood chat groups so people who live near one another can stay in touch and help one another outside of work. We have established comfort areas near the ICUs for people to relax and get a snack, etc. The Cleveland Clinic started a 24-hour caregiver hotline staffed 7 days a week by behavioural health professionals. We posted the Staff Going Home Checklist, ${ }^{1}$ which we found on Twitter, on monitors in our intensive care units. The idea is to encourage individuals to think of something bad that happened that day and let it go, think of three good things that happened and be thankful for them, check on their colleagues, and then put the day behind them, go home and spend time with their families.

\section{ARE THERE ANY READINGS THAT YOU FIND HELPFUL FOR INSPIRATION AND SUPPORT THAT YOU WOULD RECOMMEND TO OTHERS?}

Just before this happened, I read a couple of books that I found most helpful for this. The first is The Speed of Trust by Stephen Covey and Rebecca Merrill. ${ }^{2}$ I found it extremely valuable to have a team where we already established a high level of trust. The other book was Principles by Ray Dalio. ${ }^{3}$ I related to it because I'm not a pessimist or an optimist. I'm more of a realist/ pragmatist. I believe in having an open mind and in the importance of ownership. Owning a project does not mean doing all the work but rather making sure the work is done. Whether it is leading a large organisation or organising a backyard barbecue, somebody has to own it to be successful. Otherwise somebody will forget the buns!

\section{WHAT ARE YOU LOOKING FOR FROM YOUR LEADERS?}

I believe in a progressive serving leadership style that adapts to the situation and focuses on active listening, collaboration, ownership, accountability, and data-driven decision making. Leaders should have the capacity to embrace, adapt to and lead 
change and foster innovation. I expect astrong commitment to diversity and equity with the ability to identify, recruit, and retain diverse talent to build high functioning teams. Good leaders can capitalize on strengths, provide opportunities, remove obstacles, and give individuals and teams the tools and support they need to fully utilize available resources. The best leaders have the ability to do all that while also mentoring and coaching others to become progressive serving leaders.

Raed A Dweik, ${ }^{1}$ Amit Nigam (D) 2

${ }^{1}$ Respiratory Institute, Cleveland Clinic, Cleveland, Ohio, USA

${ }^{2}$ Cass Business School, City, University of London, London, UK

\section{Correspondence to}

Professor Amit Nigam, Cass Business School, City, University of London, London EC1Y 8TZ, UK; Amit.Nigam.1@city.ac.uk

Contributors RAD drew on his experience to offer his perspective on the questions that were the focus of the interview. AN conducted the interview.

Funding The authors have not declared a specific grant for this research from any funding agency in the public, commercial or not-for-profit sectors.

Competing interests None declared.

Patient consent for publication Not required.

Provenance and peer review Not commissioned; internally peer reviewed.
Data availability statement No data are available.

(C) Author(s) (or their employer(s)) 2020. No commercial re-use. See rights and permissions. Published by BMJ.

$$
\text { Check for updates }
$$

To cite: Dweik RA, Nigam A. BMJ Leader 2020;4:157-159.

Received 30 April 2020

Revised 30 April 2020

Accepted 1 May 2020

Published Online First 18 May 2020

BMJ Leader 2020:4:157-159.

doi:10.1136/leader-2020-000278

\section{ORCID iD}

Amit Nigam http://orcid.org/0000-0002-6772-9643

\section{REFERENCES}

1 Salford Care Organization Northern Care Alliance NHS Group. Staff going home checklist 2020.

2 Covey SR, Merrill RR. The speed of trust: the one thing that changes everything. Simon and Schuster, 2006.

3 Dalio R. Principles: Simon and Schuster 2018. 